\title{
FACS-GAL isolation of $\beta$-galactosidase expressing cells from mid gestation mouse embryos
}

Kelly Lammerts van Bueren

University of California at San Francisco

Peter Scambler

University College London Institute of Child Health

\section{Method Article}

Keywords: gene trap, FACS-Gal, microarray, mouse model

Posted Date: August 20th, 2009

DOI: https://doi.org/10.1038/nprot.2009.164

License: () (7) This work is licensed under a Creative Commons Attribution 4.0 International License. Read Full License 


\section{Abstract \\ Introduction}

Microarray analysis and RNA-Seq are powerful tools for investigating differential gene expression in animal models of human genetic disease. Often, these models are loss of function mutations introduced by gene targeting or trapping. One difficulty in such experiments, especially where work on congenital malformations is concerned, is that whole embryo or regional dissections will commonly contain cells that do not express the gene of interest. Thus where cell autonomous effects are of primary interest, for example in the case of transcriptional regulators, such experiments will be compromised by dilutional effects and perhaps secondary effects on surrounding, non expressing tissues. Isolation of the relevant expressing lineage can mitigate these effects. Flow cytometry offers one route to cell purification but requires a fluorescent marker, and relatively few fluorescent protein gene reporters are available. FACS-Gal $\backslash(1)$ offers the potential to capitalize upon the large existing repository of LacZ trapped ES lines now encompassing approximately $33 \%$ of all mouse genes "http://www.genetrap.org/index.html":http://www.genetrap.org/index.html. Moreover, the existence of Cre-reversible traps opens the way to within group comparisons of flow sorted cells, one pool having had expression restored using a tamoxifen activated Cre enzyme $\backslash(2)$.

\section{Reagents}

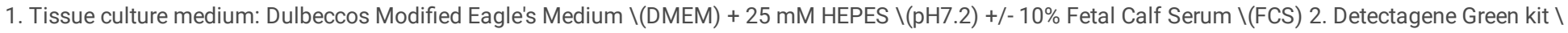
(Molecular Probes D-2920) 5-chloromethylfluorescin di- $\beta$-D-galactopyranoside $\backslash$ (CMFDG) LacZ gene expression kit $\backslash$ (note, we obtained inferior results with the ImaGene Green $\mathrm{Cl(12)FDG} \mathrm{kit)} \mathrm{3.} 0.3 \mathrm{mM}$ chloroquine diluted in DMEM + $25 \mathrm{mM}$ HEPES $\backslash(\mathrm{pH} 7.2)$ containing $5 \%$ FCS $6.50 \mu \mathrm{M}$ CMDFG, $200 \mu \mathrm{M}$ verapamil in 5\% FCS/DMEM + 25 mM HEPES $\backslash(\mathrm{pH7}$.2) 5. 1mM 2-Phenylethyl $\beta$-D-thiogalactoside Sigma, Cat. P4902 7. 1.5 $\mu$ M propidium iodide Sigma, Cat. P4170 8. Phosphate buffered saline \(PBS) 9. 0.25\% trypsin \(Gibco) in PBS

\section{Equipment}

Low speed, bench top microfuge Plastic, bulb topped pipettes Tissue culture incubator

\section{Procedure}

${ }^{* \star}$ A. Isolation of embryos** 1. Dissect out mouse embryos in DMEM $+25 \mathrm{mM}$ HEPES 2 . Embryos should be staged by somite counting to avoid noise due to normal intra and inter litter variation in development 3. If rapid genotyping $\backslash$ (or assignment of genotype by phenotype) is possible embryos may be pooled, otherwise process separately in microtitre well plates **B. CMFDG labelling of a single cell suspension** 1 . In order to reduce background fluorescence block endogenous lysosomal $\beta$-galactosidase activity by incubating embryos in $0.3 \mathrm{mM}$ chloroquine diluted in DMEM $+25 \mathrm{mM}$ HEPES containing $5 \%$ FCS and incubated at $37^{\circ} \mathrm{C}, 5 \% \mathrm{CO}_{2}$ for 30 minutes 2 . Rinse embryos three times in PBS, then incubate in $0.25 \%$ trypsin in PBS for approximately 30 minutes 3 . During step 2 dissociate embryos into a single cell suspension by trituration every 5-10 minutes using plastic pipettes, starting with larger tips and moving down to smaller tips 4 . Spin down the cell suspension at $300 \times \mathrm{g}$ for 3 minutes and resuspend in pre-warmed $\backslash\left(10\right.$ minutes at $\left.37^{\circ} \mathrm{C}\right) 50 \mu \mathrm{M} \mathrm{CMDFG}, 200 \mu \mathrm{M}$ verapamil in $5 \% \mathrm{FCS} / \mathrm{DMEM}+25 \mathrm{mM}$ HEPES and incubate for 30 minutes at $37^{\circ} \mathrm{C}, 5 \% \mathrm{CO}$. \(Note: the verapamil is used to inhibit efflux of the fluorescent, CMFDGglutathione adduct from the cells $\backslash(3)) 5$. Place cells on ice and dilute to approximately $1-3$ million cells/mL with $5 \%$ FCS/DMEM + 25 mM HEPES 6 . Add $1 \mathrm{mM}$ PETG to stop the reaction 7. Add $1.5 \mu \mathrm{M}$ propidium iodide to identify dead cells 8 . Flow sort as soon as possible $\backslash$ (standard procedures) $\star \star C$. Post FACS Treatment Notes** 1. For RNA isolation collect sorted cells immediately at $300 \mathrm{x} \mathrm{g}$ for 4 minutes and resuspended in $800 \mu \mathrm{l} \mathrm{Trizol} \backslash(\mathrm{Gibco} \mathrm{BRL})$. $250 \mu \mathrm{g} / \mathrm{ml}$ glycogen $\backslash$ (Roche) or $50 \mu \mathrm{g} / \mathrm{mL}$ Glycoblue $\backslash$ (Ambion) can be added as an RNA co-precipitant to improve yield 2. Homogenize cells by passing them twice through a 25 -gauge needle $\backslash$ (shears genomic DNA) and store at $-80^{\circ} \mathrm{C}$, or process immediately using standard techniques 3 . For microarray, we found exponential amplification worked well $\backslash(4)$ and preserved transcript abundance

\section{Timing}

Approximately 6 hours $\backslash$ (including FACS).

\section{Critical Steps}

B2. This has to be as gentle but as complete as possible in order to maximize the yield of cells. It is worth practising on wild type embryos prior to the experiment and using a standard viability stain to assess operator competency. B8. Once again this helps with cell viability and improves RNA transcript integrity.

\section{Troubleshooting}

1. Poor signal:noise ratio due to low LacZ-induced fluorescence. This may be inherent due to the expression level of the gene concerned. Variations of the protocol include: a. alteration of the CMDFG incubation period b. try incubating at $4{ }^{\circ} \mathrm{C}$ rather than $37^{\circ} \mathrm{C} 2$. Poor cell viability a. decrease number of trituration steps, but use a cell strainer $\backslash(70 \mu \mathrm{m}$ mesh size, BD Biosciences Cat. 352350) b. omit the chloroquine incubation step 3. Try FDG loading

"http://www.natureprotocols.com/2008/08/06/detection_of_lacz_expression_b.php":http://www.natureprotocols.com/2008/08/06/detection_of_lacz_expressi

\section{Anticipated Results}


The loading technique typically results in $50 \%$ cell death in the fluorescent population. A population of highly fluorescing cells should be detectable.

\section{References}

1. Fiering,S.N. et al. Improved FACS-Gal: flow cytometric analysis and sorting of viable eukaryotic cells expressing reporter gene constructs. Cytometry 12, 291$301 \backslash(1991)$. 2. Hayashi,S. \& McMahon,A.P. Efficient recombination in diverse tissues by a tamoxifen-inducible form of Cre: a tool for temporally regulated gene activation/inactivation in the mouse. Dev. Biol. 244, 305-318 \(2002). 3. Poot,M. \& Arttamangkul,S. Verapamil inhibition of enzymatic product efflux leads to improved detection of beta-galactosidase activity in lacZ-transfected cells. Cytometry. 28, 36-41 \(1997). 4. Iscove,N.N. et al. Representation is faithfully preserved in global cDNA amplified exponentially from sub-picogram quantities of mRNA. Nat. Biotechnol. 20,940-943 \(2002).

\section{Acknowledgements}

The British Heart Foundation funded our work in this area. 